\title{
IMPLIKASI EFISIENSI MODAL KERJA TERHADAP PROFITABILITAS
}

\author{
Andi Riyanto ${ }^{1}$, Galih Raspati ${ }^{2}$,Yuri Rahayu ${ }^{3}$ dan Dicki Prayudi ${ }^{4}$ \\ ${ }^{1}$ Program Studi Sistem Informasi Akuntansi, Universitas BSI PSDKU Kampus Kota Sukabumi \\ Email: andi.iio@bsi.ac.id \\ ${ }^{2}$ Program Studi Manajemen, STIE Pasim Sukabumi \\ Email: galih_raspati@yahoo.com \\ ${ }^{3}$ Program Studi Sistem Informasi Akuntansi, Universitas BSI PSDKU Kampus Kota Sukabumi \\ Email:yuri.yru@bsi.ac.id \\ ${ }^{4}$ Program Studi Sistem Informasi Akuntansi, Universitas BSI PSDKU Kampus Kota Sukabumi \\ Email:Dicki.DCD@bsi.ac.id
}

Masuk : 11-04-2019, revisi: 08-07-2019, diterima untuk diterbitkan : 09-08-2019

\begin{abstract}
ABSTRAK
Profitabilitas dalam pengelolaan modal kerja perusahaan merupakan hal yang sangat penting, karena bagaimanapun tujuan setiap kegiatan perusahaan adalah untuk memperoleh laba, dan salah satu cara untuk memperoleh kenaikan laba yang signifikan adalah dengan meningkatkan efisiensi penggunaan dana perusahaan melalui pengelolaan modal kerja. Akan tetapi laba yang tinggi belumlah merupakan ukuran bahwa perusahaan itu telah dapat bekerja dengan efisien. Tujuan penelitian untuk mengetahui implikasi efisiensi modal kerja terhadap tingkat profitabilitas pada PT. Agronesia Saripetojo Sukabumi dengan cara mengolah data sekunder berupa Laporan Keuangan perusahaan periode 2013 - 2017. Metode yang digunakan dalam penelitian ini adalah expose facto, uji statistik digunakan dengan melakukan pembuktian terhadap hipotesis. Hasil penelitian membuktikan efisiensi modal kerja berimplikasi signifikan terhadap profitabilitas.
\end{abstract}

Kata Kunci : efisiensi, modal kerja, profitabilitas.

\begin{abstract}
Profitability in managing company working capital is very important, because after all the purpose of each company's activities is to make a profit, and one way to obtain a significant increase in profits is to increase the efficiency of using company funds through working capital management. However, high profits are not yet a measure that the company has been able to work efficiently. The purpose of this study was to determine the implications of working capital efficiency on the level of profitability at PT. Agronesia Saripetojo Sukabumi by processing secondary data in the form of corporate financial statements for the period 2013-2017. The method used in this study is expose facto, statistical tests are used by proving hypotheses. The results of the study prove the efficiency of working capital has significant implications for profitability.
\end{abstract}

Keywords: efficiency, working capital, profitability

\section{PENDAHULUAN}

\section{Latar Belakang}

Efisiensi operasi perusahaan sangat berperan penting terhadap keberhasilan perusahaan berupa pertumbuhan penjualan yang meningkat. Rencana perusahaan untuk meningkatkan pertumbuhan penjualan tentu membutuhkan adanya penambahan pembiayaan modal kerja, baik pembiayaan dalam aset lancar maupun aset tetap. Pembiayaan dalam aset lancar merupakan jumlah yang relatif besar dalam perusahaan sehingga memerlukan perhatian yang seksama dari pihak manajemen terutama yang berkaitan dengan modal kerja. Keberhasilan perusahaan dalam mencapai tujuannya, tidak hanya dilihat dari besarnya profit yang diperoleh, tetapi harus dilihat dari berbagai aspek, dan salah satunya adalah aspek profitabilitas keuangan perusahaan. 
PT. Agronesia merupakan salah satu aset pemerintah daerah dibawah divisi industri yang memiliki 4 (empat) pabrik yang tersebar di wilayah Jawa Barat, yaitu industri teknik karet dengan merk dagang "Inkaba", industri plastik dan AMDK dengan merk dagang "Agroplas", industri es balok dengan merk dagang "Saripetojo" dan industri makanan dengan merk "BMC". Sedangkan PT. Agronesia Saripetojo Sukabumi berdiri sejak tanggal 17 Juni 2002, bergerak dalam bidang industri es dengan berbagai macam jenis es, yaitu es balok, es cube, dan es carving. Dalam menjalankan aktivitas operasionalnya, PT. Agronesia Saripetojo dituntut untuk mempunyai modal kerja yang berkecukupan. Modal kerja pada PT. Agronesia Saripetojo digunakan untuk membiayai kegiatan operasional perusahaan seperti membayar gaji karyawan, pembelian mesin, dan lain-lain. Modal kerja yang digunakan untuk membiayai aktivitas perusahaan akan berotasi dan masuk kembali melalui aktivitas penjualan. Dengan penjualan tersebut, PT. Agronesia Saripetojo diharapkan memperoleh profit atau laba yang akan digunakan lagi sebagai modal kerja perusahaan untuk periode selanjutnya. Maka dari itu efisiensi modal kerja perlu dilaksanakan dengan tujuan untuk memperlancar aktivitas operasional perusahaan.

Efisiensi penggunaan dana secara kontinyu akan berakibat pada nominal tingkat profitabilitas yang dihasilkan dari investasi yang dilakukan oleh perusahaan atau disebut juga dengan tingkat rentabilitas (Riyanto, 2012). Dana dalam hal ini adalah tingkat modal kerja yang digunakan untuk membiayai aktivitas operasional perusahaan yang dapat mempengaruhi besarnya profitabilitas perusahaan. Berdasarkan alasan tersebut, cukup menarik untuk membahas implikasi efisiensi modal kerja terhadap profitabilitas pada PT. Agronesia Saripetojo Sukabumi.

Beberapa hasil riset terdahulu menunjukkan bahwa rasio lancar (current ratio), perputaran modal kerja (working capital turnover), rasio perputaran perpesediaan (inventory turnover ratio) dan rasio perputaran piutang (debtors turnover ratio) berpengaruh positif terhadap ROI. Rasio cepat (acid test ratio), rasio aset lancar terhadap total aset (current assets to total assets ratio), rasio aset lancar terhadap total penjualan (current assets to sales ratio) dan perputaran kas (cash turnover ratio) berpengaruh negatif terhadap ROI (Rajesh \& Reddy, 2011). Riset lainnya menyatakan bahwa secara parsial modal kerja berpengaruh positif signifikan terhadap profitabilitas (Ambarwati, Yuniarta, \& Sinarwati, 2015). Kemudian hasil riset lainnya menyatakan bahwa beberapa fitur dalam modal kerja memiliki efek yang sangat penting pada profitabilitas perusahaan (Wijaya, 2012).

Tujuan dari penelitian ini secara keseluruhan adalah untuk mengetahui sejauhmana implikasi efisiensi modal kerja terhadap tingkat profitabilitas pada PT. Agronesia Saripetojo Sukabumi yang nantinya diharapkan dapat dijadikan rujukan bagi perusahaan dalam mengelola dan mengefisiensikan modal kerja yang ada.

\section{Rumusan Masalah}

Rumusan masalah yang diambil berdasarkan penjelasan diatas adalah sejauh mana efisiensi modal kerja pada PT. Agronesia Saripetojo Sukabumi, sejauhmana tingkat profitabilitas PT. Agronesia Saripetojo dalam 5 tahun terakhir, dan sejauhmana implikasi efisiensi modal kerja terhadap profitabilitas PT. Agronesia Saripetojo Sukabumi.

\section{METODE PENELITIAN}

Metode dalam penelitian ini adalah metode exspose facto, yaitu penelitian tentang variabel yang peristiwanya sudah terjadi sebelum penelitian dilaksanakan. Dalam penelitian ini yang menjadi 
unit analisis adalah laporan keuangan multiyear PT. Agronesia Saripetojo Sukabumi dari 2013 sampai 2017.

Data yang dibutuhkan dalam penelitian ini adalah data sekunder, yaitu data yang diperoleh langsung dari laporan keuangan, dimana data tersebut sangat jelas memperlihatkan perkembangan modal kerja perusahaan dan profitabilitas perusahaan.

Untuk melihat relasi dari variabel X dan Y maka dilakukan pengujian hipotesis. Uji hipotesis menggunakan uji dua belah pihak. Persamaan yang digunakan untuk menguji hipotesis nol dan hipotesis alternatif ditolak atau diterima adalah dengan uji t.

$\mathrm{t}=\frac{r \sqrt{n-2}}{\sqrt{1-r^{2}}}$

dengan $\mathrm{t}=$ profitabilitas, $\mathrm{r}=$ koefisien korelasi, $\mathrm{n}=$ jumlah sampel dan tingkat signifikansi $\alpha=$ 0,05 .

Hasil dari perhitungan statistik uji $\mathrm{t}(\mathrm{t}$ hitung) selanjutnya dibandingkan dengan $\mathrm{t}$ tabel. Dengan $\mathrm{dk}=\mathrm{n}-2$ dan tingkat $\mathrm{a}=0,05$, artinya jika hipotesis nol ditolak dengan taraf signifikansi 95\%, maka dapat disimpulkan hipotesis tersebut berada pada tingkat kebenaran $95 \%$ dan hal ini menunjukan adanya korelasi yang signifikan antara dua variabel tersebut.

Kriteria ditolak atau tidaknya hipotesis dinyatakan sebagai berikut :

1. Jika $\mathrm{t}$ hitung $>\mathrm{t}$ tabel maka $\mathrm{H}_{0}$ ada didaerah penolakan, berarti Ha diterima artinya ada pengaruh antara modal kerja terhadap tingkat profitabilitas pada PT. Agronesia Saripetojo Sukabumi.

2. Jika $\mathrm{t}$ hitung $<\mathrm{t}$ tabel maka $\mathrm{H}_{0}$ ada didaerah penerimaan, berarti Ha ditolak artinya tidak ada pengaruh antara modal kerja terhadap tingkat profitabilitas Pada PT. Agronesia Saripetojo Sukabumi.

Metode analisis data dalam penelitian ini menggunakan korelasi product moment, koefisien determinasi dan regresi linier sederhana. Koefisien korelasi digunakan untuk membuktikan hipotesis relasi dua variabel bila data kedua variabel tersebut berbentuk interval atau rasio, dan sumber data dari dua variabel tersebut atau bahkan lebih dari dua variabel, dapat dikatakan adalah sama. Persamaan sederhana yang dapat digunakan untuk menghitung koefisien korelasi, yaitu :

$r x y=\frac{n \sum x_{i} y_{i}-\left(\sum x_{i}\right)\left(\sum y_{i}\right)}{\sqrt{\left(n \sum x_{i}^{2}-\left(x_{i}\right)^{2}\right)\left(n \sum y_{i}^{2}-\left(y_{i}\right)^{2}\right)}}$

dengan $r \mathrm{xy}=$ korelasi antara variabel $\mathrm{x}$ dan $\mathrm{y}, \mathrm{x}=(\mathrm{xy}-\mathrm{x})$, dan $\mathrm{y}=(\mathrm{yx}-\mathrm{y})$.

Pada hakikatnya, nilai koefisien korelasi (r) selalu terletak antara -1 dan $+1(-1<\mathrm{r}<+1)$, dimana bila :

$\mathrm{r}=+1$ : Menunjukan bahwa terdapat korelasi positif antara variabel $\mathrm{X}$ dan variabel $\mathrm{Y}$. Artinya semakin besar nilai $\mathrm{X}$ semakin besar pula nilai $\mathrm{Y}$, dan sebaliknya, semakin kecil nilai $\mathrm{X}$ maka semakin kecil pula nilai Y. 
$\mathrm{r}=-1$ : Menunjukan bahwa terdapat korelasi negatif antara variabel $\mathrm{X}$ dan variabel $\mathrm{Y}$. Artinya semakin besar nilai $\mathrm{X}$ semakin kecil nilai $\mathrm{Y}$, atau sebaliknya, semakin kecil nilai $\mathrm{X}$ semakin besar pula nilai Y.

$\mathrm{r}=0 \quad$ : Menunjukan bahwa tidak terdapat korelasi antara $\mathrm{X}$ dan $\mathrm{Y}$.

Kriteria penafsiran terhadap koefisien korelasi yang ditemukan tersebut sangat kuat ataupun sangat rendah, dapat berpedoman pada ketentuan berikut :

Tabel 1 Kriteria Interprestasi Terhadap Koefisien Korelasi

Sumber : (Sugiyono, 2010).

\begin{tabular}{cc}
\hline Interval Koefisien & Tingkat Hubungan \\
\hline $0,00-0,199$ & Sangat Rendah \\
\hline $0,20-0,399$ & Rendah \\
\hline $0,40-0,599$ & Sedang \\
\hline $0,60-0,799$ & Kuat \\
\hline $0,80-1,00$ & Sangat Kuat \\
\hline
\end{tabular}

Korelasi dapat menghasilkan angka positif (+) ataupun negatif (-). Jika korelasi mendapatkan nilai positif $(+)$, hubungan kedua variabel bersifat searah. Jika korelasi menghasilkan nilai negatif (-), maka hubungan kedua variabel bersifat tidak searah. Nilai korelasi yang berkisar antara 0 sampai dengan 1, menunjukkan bahwa besar kecilnya angka korelasi tersebut menentukan kuat atau lemahnya hubungan antara kedua variabel.

Koefisien determinasi digunakan untuk mengetahui seberapa besar persentase pengaruh modal kerja sebagai variabel $\mathrm{X}$ dan tingkat probabilitas sebagai variabel $\mathrm{Y}$. Persamaan yang digunakan adalah:

$\mathrm{Kd}=r x y^{2} \times 100 \%$

Dengan $\mathrm{Kd}=$ koefisien determinasi, $\mathrm{r} x \mathrm{y}^{2}=$ koefisien korelasi, dan $100 \%=$ pengali yang dinyatakan dalam persentase.

Regresi sederhana merupakan arah untuk menentukan relasi fungsional ataupun kausal pada variabel independen dengan variabel dependen, persamaan regresi linear sederhana adalah :

$\mathrm{Y}=\mathrm{a}+\mathrm{bX}$

dengan $\mathrm{Y}=$ subjek dalam variabel dependen, $\mathrm{a}=$ harga $\mathrm{Y}$ bila $\mathrm{X}=0$ (harga konstan), $\mathrm{b}=$ nominal koefisien regresi, merupakan nominal naik atau turunnya variabel dependen (terikat) yang didasarkan pada perubahan variabel independen (bebas). Bila positif (+) arah tren naik, dan bila negatif (-) maka arah tren turun, serta $X=$ ubjek pada variabel bebas yang mempunyai nilai tertentu.

Fungsi analisis regresi untuk membuat keputusan apakah tren naik dan turunnya variabel terikat dapat dilakukan melalui peningkatan variabel bebas atau tidak.

Sehingga untuk mencari a dan $b$ dinyatakan dengan persamaan : 
$\mathrm{a}=\frac{\left(\sum y i\right)\left(\sum x i^{2}\right)-\left(\sum x i\right)(x i y i)}{n \sum X i^{2}-\left(\sum x i\right)^{2}}$

$\mathrm{b}=\frac{n \sum X i Y i-\left(\sum X i\right)\left(\sum Y i\right)}{n \sum X i^{2}-\left(\sum X i\right)^{2}}$

dengan $\mathrm{Y}=$ variabel dependen (profitabilitas), $\mathrm{X}=$ variabel independen (modal kerja), $\mathrm{n}=$ banyaknya sampel, $\mathrm{a}=$ konstanta (harga $\mathrm{Y}$ bila $\mathrm{X}=0$ ), $\mathrm{b}=$ koefisien regresi variabel independent dan $\mathrm{n}=$ banyaknya sampel.

\section{HASIL DAN PEMBAHASAN}

Modal kerja merupakan salah satu komponen penting bagi lancar tidaknya operasional perusahaan. Tingkat kecukupan modal kerja sangat berperan penting, dimana semakin rendah modal kerja yang dimiliki perusahaan, maka aktivitas perusahaan akan terhambat, begitu pula sebaliknya. Minimnya modal kerja yang dimiliki perusahaan akan sangat mempengaruhi produktivitas perusahaan sesuai dengan tingkat pertumbuhan usahanya.

Meskipun modal kerja yang besar itu penting bagi kelancaran usaha suatu perusahaan, namun perusahaan yang memiliki modal kerja yang berlebihan dan tidak dapat mengalokasikannya secara tepat akan mengalami kerugian. Oleh karena itu, modal kerja harus seimbang dan sejalan dengan pertumbuhan usaha perusahaan dan dengan pengelolaan modal kerja secara tepat sehingga tujuan perusahaan dapat tercapai.

Fenomena laporan modal kerja perusahaan dari tahun 2013-2017 terlampir sebagai berikut:

Tabel 2 Rincian Modal Kerja PT. Agronesia Saripetojo Sukabumi Tahun 2013 - 2017 (dalam Rp.)

Sumber : Laporan Keuangan PT. Agronesia Saripetojo Sukabumi Tahun 2013 - 2017

\begin{tabular}{ccccccc}
\hline No & Perkiraan & $\mathbf{2 0 1 3}$ & $\mathbf{2 0 1 4}$ & $\mathbf{2 0 1 5}$ & $\mathbf{2 0 1 6}$ & $\mathbf{2 0 1 7}$ \\
\hline 1 & Kas & 8.748 .046 & 12.720 .000 & 21.123 .795 & 10.367 .543 & 4.476 .900 \\
\hline 2 & Bank & 5.041 .161 & 6.040 .569 & 4.327 .359 & 12.094 .105 & 12.008 .741 \\
\hline 3 & Piutang Usaha & 466.649 .257 & 227.426 .057 & 410.972 .275 & 536.276 .825 & 843.192 .466 \\
\hline 4 & Piutang Karyawan & 23.357 .833 & 6.885 .500 & 3.128 .500 & 16.715 .250 & 32.659 .025 \\
\hline 5 & Piutang Lain-lain & 82.109 .795 & 375.196 .515 & 304.509 .715 & 293.308 .415 & 292.558 .415 \\
\hline 6 & Persediaan & 26.974 .441 & 29.981 .859 & 28.418 .000 & 28.444 .020 & 55.196 .245 \\
\hline 7 & Biaya Dibayar dimuka & 58.487 .001 & 43.062 .647 & 124.696 .576 & - & - \\
\hline 8 & Uang Muka & 1.274 .629 & - & - & 5.040 .000 & 4.300 .000 \\
\hline & JUMLAH & $\mathbf{6 7 2 . 6 4 2 . 1 6 3}$ & $\mathbf{7 0 1 . 3 1 3 . 1 9 4}$ & $\mathbf{8 8 7 . 9 2 6 . 2 1 9}$ & $\mathbf{8 9 2 . 2 4 6 . 1 6 2}$ & $\mathbf{1 . 3 0 6 . 1 4 1 . 7 9 5}$ \\
\hline
\end{tabular}

Dari table 2 menunjukan adanya peningkatan jumlah Modal kerja setiap tahunya Antara $10 \%$ $14 \%$.

Sedangkan untuk mengetahui bagaimana perkembangan modal kerja yang ada di PT. Agronesia Saripetojo Sukabumi maka dapat dilihat dari tabel di bawah ini : 
Tabel 3 Perkembangan Modal Kerja PT. Agronesia Saripetojo Sukabumi dari tahun 2013-2017 (dalam Rp.)

Sumber : Laporan Keuangan PT. Agronesia Saripetojo Sukabumi Tahun 2013 - 2017

\begin{tabular}{cc}
\hline Periode & Modal Kerja \\
\hline 2013 & 672.642 .163 \\
\hline 2014 & 701.313 .194 \\
\hline 2015 & 887.926 .219 \\
\hline 2016 & 892.246 .162 \\
\hline 2017 & 1.306 .141 .795 \\
\hline
\end{tabular}

Dari tabel 3, terlihat bahwa perkembangan modal kerja PT. Agronesia Saripetojo Sukabumi dalam pertahunnya terus meningkat, akan tetapi apabila dilihat dari perkembangan persentase pertahunnya mengalami fluktuasi. seperti pada tahun 2013 perolehan persentase modal kerja sebesar -18,52\% dan ditahun 2014 perolehan persentase modal kerja sebesar 4,26\% hal ini menunjukan bahwa pada tahun tersebut mengalami kenaikan perolehan persentase modal kerja. Kemudian tahun 2014 sampai tahun 2015 perolehan persentase modal kerja mengalami kenaikan sebesar 26,60\%. Pada tahun 2015 dari perolehan persentase modal kerja tahun 2014 dengan selisih persentase sebesar $22,34 \%$, ditahun berikutnya perolehan persentase modal kerja kembali menurun dari 26,60\% ditahun 2015 ke 0,49\% ditahun 2016, ditahun selanjutnya pada tahun 2017 perolehan persentase modal kerja kembali naik sebesar 46,38\%. Ini berdasarkan perbandingan persentase pertahunnya, maka dapat terlihat bahwa terjadi fluktuasi perolehan persentase modal kerja, hal ini dapat disebabkan karena berbagai faktor yang mengakibatkan modal kerja pada PT. Agronesia Saripetojo Sukabumi tersebut mengalami fluktuasi. Akan tetapi kenaikan nilai modal kerja lebih mendominasi dibandingkan dengan penurunannya. Hal itu disebabkan karena semakin baiknya dalam pengelolaan modal kerja terutama pada pos aktiva lancar di perusahaan tersebut. Dan kenaikan angka tertinggi terjadi pada tahun 2015 dan 2016, hal ini disebabkan karena meningkatnya jumlah pada pos aktiva lancar daripada kewajiban lancar.

Perkembangan modal kerja berdasarkan persentase pertahunnya terlihat pada grafik dibawah ini:

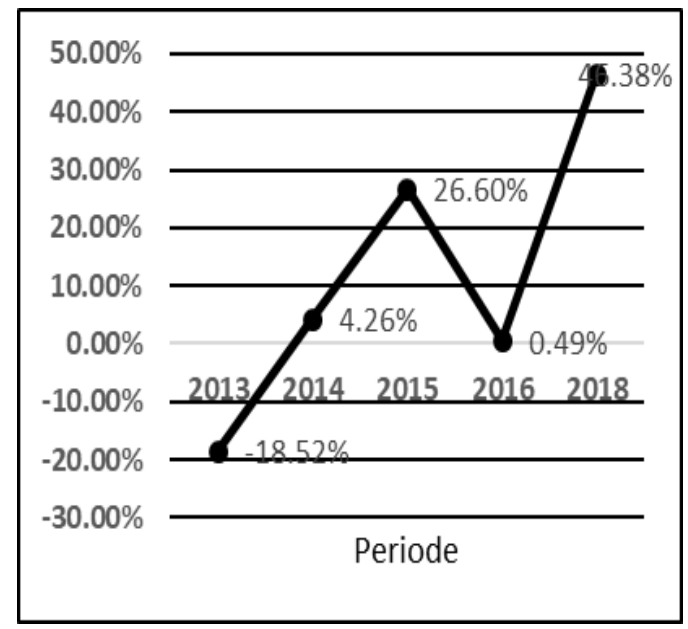

Gambar 1 Perkembangan Modal Kerja PT. Agronesia Saripetojo Sukabumi Tahun 2013 - 2017 Sumber : Data yang diolah (2019). 
Dari grafik diatas terlihat sangat jelas dari tahun ke tahun modal kerja mengalami kenaikan dan penurunan terlihat di tahun 2013 ke tahun 2014 mengalami kenaikan dari defisit -18,52\% bisa menjadi surplus 4,26\% dan di tahun 2015 terus naik lagi di angka 26,60\% ini menunjukan tend bahwa pengelolaan modal kerja sudah bisa dilakukan dengan baik yang mengandung arti kinerja manajemen sudah lebih baik. Walapun di tahun 2016 mengalami penurunan kembali tapi tidak dalam posisi defisit.

Profitabilitas merupakan ukuran aksebilitas perusahaan dalam menghasilkan profit selama periode tertentu. Penentuan kriteria tingkat profitabilitas, suatu perusahaan perlu mempertimbangkan pengukuran yang mapan terhadap modal kerja, karena akibat kesalahan dalam menetapkan operasional modal kerja akan mengganggu aktivitas operasional perusahaan secara keseluruhan. Perkembangan profitabilitas PT. Agronesia Saripetojo Sukabumi dari tahun 2013 sampai dengan 2017 adalah sebagai berikut :

Tabel 4 Pertumbuhan Profitabilitas PT. Agronesia Saripetojo Sukabumi Tahun 2013 - 2017 (dalam Rp.)

Sumber : Laporan Keuangan PT. Agronesia Saripetojo Sukabumi Tahun 2013 - 2017

\begin{tabular}{ccc}
\hline Periode & Laba & Modal \\
\hline 2013 & 245.335 .557 & 245.335 .557 \\
\hline 2014 & 395.249 .980 & 579.016 .938 \\
\hline 2015 & 675.206 .031 & 1.254 .222 .969 \\
\hline 2016 & -80.751 .337 & 1.048 .775 .056 \\
\hline 2017 & 366.977 .348 & 1.415 .752 .404 \\
\hline
\end{tabular}

Dari tabel diatas terlihat perkembangan profitabilitas dari tahun ke tahun terjadi fluktuasi. Sehingga untuk melihat bagaimana perubahan tingkat profitabilitas setiap tahunnya dapat dilihat dalam grafik dibawah ini :

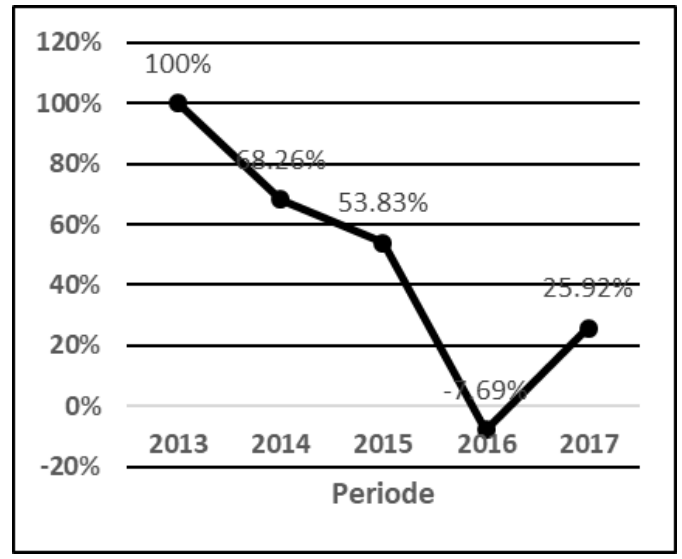

Gambar 2 Perubahan Tingkat Profitabilitas PT. Agronesia Saripetojo Sukabumi

Tahun 2013 - 2017

Sumber : Data yang diolah (2019).

Dari grafik terlihat sangat jelas bahwa perkembangan tingkat profitabilitas dari tahun ke tahunnya stabil. Akan tetapi terdapat penurunan yang mendominasi dari tahun 2015 sampai tahun 2016, walaupun tidak setiap tahunnya penurunan terjadi. Tingkat profitabilitas terendah terjadi pada tahun 2016 yaitu $-7,69 \%$, hal ini disebabkan karena tingginya total aktiva sebagai 
akibat dari besarnya jumlah piutang yang ada pada PT. Agronesia Saripetojo Sukabumi, dan tingkat profitabilitas tertinggi terjadi pada tahun 2013 yaitu sebesar $100 \%$.

Modal kerja dengan tingkat profitabilitas PT. Agronesia Saripetojo Sukabumi tahun 2013 sampai dengan 2017 dapat dilihat pada tabel berikut :

Tabel 5 Perbandingan Modal Kerja dan Tingkat Profitabilitas PT. Agronesia Saripetojo Sukabumi Tahun 2013-2017

Sumber : Data yang diolah (2019).

\begin{tabular}{ccc}
\hline Periode & Modal Kerja & Tingkat Profitabilitas \\
\hline 2013 & -0.1852 & 1.00 \\
\hline 2014 & 0.426 & 0.6826 \\
\hline 2015 & 0.2660 & 0.5383 \\
\hline 2016 & 0.0049 & -0.0769 \\
\hline 2017 & 0.4638 & 0.2592 \\
\hline
\end{tabular}

Dari tabel diatas dapat diketahui tingkat korelasi product moment, koefisien determinasi, regresi linear sederhana dan pengujian hipotesis dengan hasil sebagai berikut:

Tabel 6 Korelasi Modal Kerja Terhadap Tingkat Profitabilitas Sumber : Data yang diolah (2019).

\begin{tabular}{|c|c|}
\hline Variabel & Tingkat Profitabilitas \\
\hline Modal Kerja & 0,920 \\
\hline \multicolumn{2}{|c|}{ Signifikan $(2$-tailed $)=0,027$} \\
\hline $\mathrm{N}$ & $=5$ \\
\hline Level Signifikan & $=0,05$ \\
\hline
\end{tabular}

Berdasarkan perhitungan pada tabel 6 dapat dijelaskan bahwa diketahui $\mathrm{r}>0$ yaitu $0,920, \mathrm{~N}+$ banyaknya data 5 (tahun 2013 - 2018), tingkat kesalahan $5 \%$. Artinya terjadi hubungan yang sangat kuat antara modal kerja terhadap tingkat protabilitas. efek modal kerja tersebut linier positif atau searah, yaitu semakin besar modal kerja maka semakin besar pula profitabilitas pada PT. Agronesia Saripetojo Sukabumi. Sebaliknya semakin kecil modal kerja maka semakin kecil pula tingkat profitabilitas pada PT. Agronesia Saripetojo Sukabumi. Untuk meningkatkan profitabilitas PT. Agronesia Saripetojo Sukabumi maka perusahaan harus mampu meningkatkan modal kerjanya.

Tabel 7 Koefisien Determinasi Modal Kerja Terhadap Tingkat Profitabilitas Sumber : Data yang diolah (2019).

\begin{tabular}{cccc}
\hline Variabel & $\mathbf{R}$ & $\mathbf{R}^{\mathbf{2}}$ & ${\text { Adjusted } \mathbf{R}^{2}}$ \\
\hline Modal Kerja & 0,920 & 0,846 & 0,795 \\
\hline
\end{tabular}

Untuk mengetahui implikasi modal kerja terhadap tingkat profitabilitas maka digunakan angka $\mathrm{R}$ Square atau Koefisien determinasi (Kd). Dari perhitungan pada tabel 7 diperoleh nilai koefisien determinasi sebesar 0,846 . Ini berarti bahwa tingkat profitabilitas dipengaruhi oleh modal kerja sebesar $84,6 \%$, sedangkan sisanya $15,4 \%$ dipengaruhi oleh faktor-faktor keuangan lain yang ada di perusahaan. Sedangkan 0,920 mengandung arti bahwa terjadi tingkat hubungan yang sangat kuat Antara Modal kerja terhadap tingkat propfitabilitas (berdasarkan table 1 kreteria interprestasi terhadap koefisien korelasi) dan 0,795 (79,5\%) mengandung arti bahwa kontribusi 
X1 (modal kerja) mempengaruhi variable Y (tingkat Profitabilitas) dan sisanya dipengaruhi oleh variable lain diluar variable yang diuji.

Tabel 8 Konstanta dan Uji t Modal Kerja Terhadap Tingkat Profitabiltas

Sumber : Data yang diolah (2019).

\begin{tabular}{ccccc}
\hline Variabel & Koefisien & Nilai t hitung & Nilai t tabel & Signifikansi \\
\hline (Constant) (a) & 0,217 & 2,054 & - & 0,132 \\
\hline Modal Kerja (b) & 1,353 & 4,064 & 3,182 & 0,027 \\
\hline F hitung & 16,519 & - & - & 0,027 \\
\hline
\end{tabular}

Dari tabel 8 terlihat nilai a atau konstanta sebesar 0,217 yang mempunyai arti, jika tidak ada peningkatan modal kerja maka profitabilitas sebesar 0,217 dan nilai b sebesar 1,353 . Karena $b$ bernilai positif, maka menunjukan hubungan yang searah artinya setiap terjadinya kenaikan modal kerja maka tingkat profitabilitas akan mengalami kenaikan sebesar 1,353 pada PT. Agronesia Saripetojo Sukabumi.

Uji t untuk menguji signifikansi hipotesis, dimana :

Ho = Tidak ada implikasi antara modal kerja terhadap tingkat profitabilitas.

$\mathrm{Ha}=$ Ada implikasi antara modal kerja terhadap tingkat profitabilitas.

Berdasarkan tingkat signifikansi :

Jika > 0,05 maka Ho diterima

Jika $<0,05$ maka Ha ditolak

Berdasarkan tabel 8, diperoleh angka signifikansi sebesar 0,027 artinya lebih kecil dari 0,05 dan berdasarkan tabel distribusi $t$, besarnya t tabel dengan derajat kebebasan (df) $n-2$ dan $\alpha=0,05$ atau tingkat kepercayaan 95\%. Karena pengujian dilakukan dengan dua sisi atau dua pihak maka $\alpha$ yang digunakan adalah $\alpha / 2$ maka $t$ tabel adalah sebesar 3,182. Karena nilai t hitung lebih besar dari t tabel yaitu 4,064 > 3,182 maka Ho berada di daerah penolakan sehingga keputusannya menerima Ha, artinya terdapat implikasi yang positif (signifikan) antara modal kerja terhadap tingkat profitabilitas pada PT. Agronesia Saripetojo Sukabumi, artinya jika modal kerja semakin tinggi maka profitabilitas pada PT. Agronesia Saripetojo Sukabumi juga semakin tinggi. Sebaliknya jika modal kerja semakin rendah maka tingkat profitabilitas PT. Agronesia Saripetojo Sukabumi juga semakin rendah.

\section{KESIMPULAN DAN SARAN}

Dari hasil riset membuktikan bahwa efisiensi modal kerja berimplikasi signifikan positif terhadap tingkat profitabilitas PT. Agronesia Saripetojo Sukabumi.

Saran yang dapat diberikan kepada perusahaan, PT. Agronesia Saripetojo Sukabumi harus bisa meningkatkan pendapatannya yang berasal dari pos aset lancar dan pos lainnya serta perusahaan harus bisa memprioritaskan beberapa aspek operasional dalam meningkatkan usaha dari ketersediaan modal yang ada. PT. Agronesia Saripetojo Sukabumi juga harus bisa mempertahankan tingkat profitabilitasnya dengan cara lebih mengoptimalkan jumlah aset lancar dan modal agar dapat menghasilkan laba yang maksimal. Diharapkan pula manajemen perusahaan dapat meningkatkan modal kerja karena dengan naiknya tingkat modal kerja maka 
akan berdampak pada naiknya tingkat profitabilitas. Untuk riset selanjutnya diharapkan fokus pada variabel keuangan lainnya selain modal kerja dan profitabilitas yang nantinya dapat dibandingkan dengan perusahaan sejenis dalam periode keuangan yang sama.

\section{Ucapan Terima Kasih (Acknowledgement)}

Kami sebagai penulis mengucapkan terima kasih yang sebesar-besarnya kepada pimpinan PT. Agronesia Saripetojo Sukabumi dan jajaran manajemen yang telah mendukung kami dalam melaksanakan riset dengan tema implikasi efisiensi modal kerja terhadap profitabilitas serta memberikan ijin kepada kami untuk mengambil data perusahaan berupa laporan keuangan historis tahun 2013 - 2017 sebagai bahan analisis.

\section{REFERENSI}

Ambarwati, N. S., Yuniarta, G. A., \& Sinarwati, N. K. (2015). Pengaruh Modal Kerja, Likuiditas, Aktivitas Dan Ukuran Perusahaan Terhadap Profitabilitas Pada Perusahaan Manufaktur Yang Terdaftar Di Bursa Efek Indonesia. JIMAT (Jurnal Ilmiah Mahasiswa Akuntansi) Undiksha, 3 (1).

Rajesh, M., \& Reddy, N. R. (2011). Impact of Working Capital Management on Firm's Profitability. Global Journal of Finance and Management, 3 (1), 151-158.

Riyanto, B. (2012). Dasar-dasar Pembelanjaan (4th ed.). Yogyakarta: BPFE.

Sugiyono. (2010). Metode Penelitian Kuantitatif Kualitatif dan R\&D. Bandung: CV Alfabeta.

Wijaya, A. L. (2012). Pengaruh Komponen Working Capital Terhadap Profitabilitas Perusahaan. Jurnal Dinamika Akuntansi, 4 (1). 